\title{
Customer Perceived Value in Social Commerce: An Exploration of Its Antecedents and Consequences
}

\author{
Haitham Hmoud Alshibly \\ Management Information Systems Department \\ Al Balqa Applied University, Jordan \\ E-mail: halshibly@gmail.com
}

Received: Dec.16, 2014

Accepted: Dec. 20, 2014

Published: January 1, 2015

doi:10.5296/jmr.v7i1.6800

URL: http://dx.doi.org/10.5296/jmr.v7i1.6800

\begin{abstract}
This study develops and empirically tests a conceptual model of customer perceived value and its antecedents and consequences on the social commerce context. The study identifies online service quality and online trust as factors influencing customer perceived value and customer satisfaction as a consequence of customer perceived value in social commerce. A detailed questionnaire was developed to measure the relationship between the aforementioned variables and data was collected from 149 Jordanian web users by email. The data was analyzed using PLS-SEM technique.

The results provided support for the theoretical model of this study. In particular, the study identified that all dimensions of perceived value were found to have a significant effect on customer satisfaction. Specifically, the study found that both social value and information value to have a significant effect on customer satisfaction.

Furthermore, the study identified that online trust and online service quality are factors having direct influence on customer information and social value. It was found, however, that online service quality is the strongest predictor of customer perceived value. Finally the study discusses the implications and scope for future research in the area.
\end{abstract}

Keywords: Social Commerce, Customer Perceived Value, Information Value, Social Value; Online Trust, online service quality. 


\section{Introduction}

Empowered by with the Web 2.0 and the diffusion of social media, mainly social networks allowed customers to create content in the web and influence each other lives and purchasing decisions. In this context, it enables bi-directional communication: between consumers and businesses, among consumers, and between consumers and third parties such as government. These bi-directional characteristics of the social network communication, giving rise to a new stream of electronic commerce (e-commerce) called social commerce (s-commerce). In s-commerce era, individuals share their knowledge, experiences, and information about the products and services with peers, providing a supportive environment in an online context. With the Web 2.0, s-commerce websites allow customers to interact and collaborate with each other in a virtual community as creators of user generated content, in contrast to websites where people are limited to the passive viewing of content.

With the benefits recognized by companies and consumers, s-commerce has been realized more and more important. It is believed that it will become an important channel for business revenues and as well as an important part of peoples' daily life. By empowering customers, s-commerce has raised customers' expectations of retailers. Indeed, they seemingly expect from s-commerce as much as, or even more than, what they expect from other alternate channels. In fact, scholars have called for research to enhance understanding of s-commerce (e.g., Kim \& Park, 2013; Huang \& Benyoucef, 2013). The current study thus seeks to address this important issue and does so vis-a' -vis customer perceived value.

Knowing where value resides from the standpoint of the customer has become critical for business, because greater levels of customer perceived value may lead to greater levels of customer satisfaction, a stronger competitive position, and, ultimately, higher market share according to Fornell et al (1992). Stahl et al (2003) claimed that the customer perceived value is a key driver for developing and maintaining a loyal consumer base, as it plays an important role in customer acquisition and retention. Eggert and Ulaga (2002) argue that those firms that deliver the kind of value that customers want are able to gain competitive advantage. Firms that recognize the importance of value perception are more likely to build relationships with their customers, making it hard for their customers to walk away and restart the learning process with another supplier (Grönroos, 1997). Marketing research has shown the context-dependent nature of perceived customer value (Zeithaml, 1988). That is, customer perceived value can change with the consumption situation (Chen \& Dubinsky, 2003).

Thus, the new consumption context of s-commerce may well lead to a change in customer perceived value relative to alternate purchase settings, as well as the factors influencing perceived consumer value. Despite its importance, information systems (IS) researchers have paid little attention to the concept and little effort has been made to its theoretical advancement in the s-commerce context.

Accordingly, this study seeks to contribute to the developing body of research into what kind of value customers derives from s-commerce. As there is a lack of literature explains how s-commerce affects customer perceived value, the research develops and empirically tests a 
conceptual model of customer perceived value and its antecedents and consequences on the s-commerce context. The study identifies online service quality and online trust as factors influencing customer perceived value in s-commerce, Therefore, this study also examines the relationships between these factors and their influence on customer perceived value. The rest of the paper is presented as follows: The first section present literature review of the constructs and hypothesis development, followed by the development of the conceptual framework. Thereafter the research design methodology, results and findings, conclusion, limitation and recommendations of the study.

\section{Literature review and hypothesis development}

\section{Customer Perceived Value}

Integrating various definitions of value into a single definition, Zeithaml (1988:14) proposed "perceived value is the consumer's overall assessment of the utility of a product based on the perceptions of what is received and what is given". Zeithaml's definition and conceptualisation of consumer perceived value is the most used and implemented in the literature. Woodruff and Gardial (1996:54) say more simply that "Value is as consumers perceive it". This definition suggests that the products are a means to an end. However, value perception appears to be highly personal. Lovelock (1991) says that value perceived could be a low price, it could be whatever a consumer wants in the product, it could be the quality a consumer gets for the price he or she pays, or it could be what a consumer gets for what he/she gives.

The traditional concept of customer perceived value revolves around the primary product or service offered by a firm, and implies that value stems from usage (Woodruff, 1997). The IS literature harmonizes this notion, positing that by using information technologies; organisations can create consumer value through improved consumer service (Feeny, 2001). E-commerce has created an easily accessible and relatively affordable, link between a firm and its consumers, and provided increasing opportunities to use IS in support of consumer service (Piccoli et al, 2004).

The importance of perceived value in general e-commerce environments also stems from the fact that it is easy to compare product features as well as prices online, and easy to switch suppliers. For example, Grewal et al (2003) say the search costs in electronic marketplaces are lower, resulting in more competitive prices to the consumer. Search costs represent the cost of the consumer to search information about another supplier's products and prices (Brynjoffson and Smith, 2000). The reduction in search costs not only increases the likelihood that consumers will compare prices, but also enables consumers to compare the benefits they may derive from the products and services that they purchase (Bakos, 1991).

In traditional retail settings, studies showed that value perception may result from different elements, such as functional elements, transactional ones, etc. The most common dimensions for the measurement of perceived value from the literature review, and retained here are utilitarian value, transactional value, and social value.

Utilitarian value is the perceived utility of a service or product based on the capacity for the utilitarian performance. The utilitarian dimension is related to as economic value for the money 
(Zeithaml, 1988), convenience and time saving (Teo, 2001). Transactional value, which results from the consumers' perceptions of a psychological satisfaction or pleasure obtained when taking advantage of the financial terms of the price deal (Grewal et al., 1998).

Generally, there are two kinds of s-commerce websites: people focused and activity focused. People focused websites emphasize social interaction through user-driven personal content; whereas activity focused social websites emphasize social interaction through site-specific content. Hence, utilitarian value can be divided into information value and social value for the users in s-commerce (Yen, 2013). Information value refers to the service providing the convenience to exchange information with others and the useful contents of information exchange, which could be the utilitarian for the users (Yen, 2013).

Social value refers to the service offering interaction targets which contribute the utilitarian to the users. Sweeney and Soutar (2001) define social value as "the utility derived from the product's ability to enhance social self-concept". Accordingly, social value derives generally from service use shared with others. In information systems adoption research, social aspects have traditionally been conceptualized as social norms, i.e., Pressure from others to use new technology (Venkatesh et al. 2003), whereas social value gained by the social commerce use has not gained much attention, and further research is encouraged in order to provide a more complete understanding of intentions to use new technology (Celuch et al., 2007).

\section{Factors influencing social commerce perceived value}

\section{Online Trust}

Trust has become a key characteristic correlated with the success or failure of many online ventures (Urban et al., 2000). For Internet companies it is much harder to promote trust than their brick-and-mortar counterparts, because of the high uncertainty existing in commerce with such vendors (Gefen et al., 2003).

In e-commerce literature, trust has been conceptualised in various ways. McKnight et al (2002), in an attempt to reconcile a vast body of literature regarding the different types of trust, develop a typology of trust consisting of five types: interpersonal trust, trusting beliefs, system trust, dispositional trust, and decision to trust.

Interpersonal trust is one actor's willingness to depend on the other actor with a feeling of security even when negative consequences are possible. Trusting beliefs are based on the individual's cognitive beliefs about the other party's characteristics (e.g., competence, integrity). Dispositional trust is a person's tendency to trust across a broad spectrum of situations and persons. Decision to trust refers to the intention to trust in particular situations. Collectively, these constructs provides a reasonable definition of trust.

However, in the context of studying s-commerce, a critical issue has hampered empirical investigations of the impact of consumer trust on s-commerce success. The issue is centred on the confusion between interpersonal trust and system trust. With interpersonal trust, trust is with a person or business, whereas trust in the system is trust in the reliability and security of the system. Pennington et al. (2003:102) define system trust as "a belief that the proper 
impersonal structures have been put into place, enabling one party to anticipate successful transactions with another party". In the on-line setting, trust not only is affected by properties attributed to the firm, but also by the electronic system mediating the transaction.

Pennington et al (2003) noted that most of the conceptualisation of trust within the e-commerce literature focuses on the risk of a situation, not so much on the question of whether the user can actively manipulate the system and intervene in the process or not. Similarly, Samarajiva (2004) notes much of the discussion in the literature around trust deals with building trust in a physical, interpersonal environment, and says little is known about how to create a trust-conducive environment based on interactive media systems.

Morgan and Hunt (1994) observe that in traditional commerce, trust follows judgment and purchase. In contrast, the trustworthiness of e-commerce firms is often evaluated before the exchange. Hsiao et al. (2010) used the term "social shopping" to describe s-commerce, claiming that social shopping is a new e-commerce method combining social networking with shopping. They conducted an empirical analysis of the factors influencing trust in product referrals and trust in websites in the context of social shopping and found that three factors representing social networks (perceived ability, perceived benevolence/ integrity, and perceived critical mass) have some bearing on trust in product referrals.

Gefen and Straub (2004) related trust to a reduction of the consumer's uncertainty, arguing that doing commerce with a seller puts them in an uncertain situation, because the vendor is generally independent and not completely predictable, and consumers are reliant on seller actions. Gefen (2000) suggested the lack of effective regulation in the e-commerce context makes consumers have to trust that the vendor will not engage in harmful opportunistic behaviours, or else the overwhelming social complexity will cause them to avoid purchasing.

This study posits that a higher level of online trust is likely to increase the s-commerce perceived value because trust is likely to reduce risk in s-commerce interactions and this in turn increases customer satisfaction. In addition, the consumer behaviour literature suggests trust is a central construct of any long-term relationship (Morgan and Hunt, 1994). Therefore, the relationships between online trust and s-commerce perceived value are hypothesized as:

$\mathrm{H}_{1}$. Online trust will positively impact information value.

$\mathrm{H}_{3}$. Online trust will positively impact social value.

\section{Online Service Quality}

Service quality on the Internet is the extent to which a website facilitates efficient and effective shopping, purchasing, and delivery of products (Zeithaml, Parasuraman, and Malhotra, 2000). As DeLone and McLean (2003, 2004) noted, service quality in the online environment is more important than previously thought. Initially it was considered that it is enough only to have a web presence and low prices in order to have a successful business (Parasuraman, 2005).

The traditional IS view of service quality revolved around the quality of the IS department service, as perceived by its users. Kim (1989) introduced consumer satisfaction research as an 
appropriate reference discipline for research into user satisfaction. The concrete cues and perceptual attributes that form the basis of consumer evaluations of service quality in an online environment, however, differ substantially from those consumers typically evaluate in traditional shopping or services, such as courtesy of the sales staff (Zeithaml et al, 2002).

The marketing and IS notions of service quality come together in e-commerce. For example, post purchase services are likely to be part of e-commerce service quality perceptions, and involve attributes such as empathy and reliability. This marks a significance shift from the functional view of service quality found in traditional IS, towards non-functional service quality aspects, according to Aladwania and Palvia (2002). Such a shift was made in Delone and Mclean's updated IS success model (2003), in which service quality was defined as "the overall support delivered by the service provider".

Nowadays, online service quality is recognised as a crucial factor used by e-marketers in their marketing strategy, in order to differentiate their services from the competitors. The service managers have to ensure that they offer high service quality, which meets or exceeds the expected by consumers service level (Ladhari, 2009).

Collier and Bienstock (2006) suggested that an online service encounter starts with a customer making a behavioural choice visiting a particular website. The website is the first experience that the consumer has with an e-retailer. Further, in their article Carlson and O'Cass (2010) noted that customers form their initial opinion en assessment of e-service quality based on the particular dimensions of the website interface, because of the limited human interaction with the e-retailer in the delivery of products or services.

Consumers evaluate the quality of products and services on the basis of informational cues that may be intrinsic to the product or service, or extrinsic (Zeithaml, 1988). As consumers possess more information about a firm's product and service quality, they become less reliant on cues (Zeithaml, 1988), for example price diminishes in its influence as a cue for product quality. Service quality in a store-based setting may be inferred from cues such as return policies and available sales personnel. Studies have found that, in such settings, service quality is an important extrinsic cue that influences consumer's perceptions of overall quality (Sweeney \& Soutar, 2001).

In addition, many researchers have found direct positive relationship between service quality and perceived value (Cronin et al., 2000; Kim et al., 2012). Cronin et al. (2000) found in their research that value is largely defined by perceptions of service quality and according to them, service consumers place greater importance on the quality of a service, than they do on the costs associated with its acquisition, i.e. service quality is an important decision-making criterion for service consumers. According to Parasuraman and Grewal (2000), service quality is a logical driver of perceived value and even in instances where the buyer-seller exchange involves a physical product, superior pre-sale and post-sale service rendered by the seller can add to the perceived value. A recent research of Chang and Wang (2011) indicated as well that online service quality has an important role in the development of perceived value in the online environment. According to the authors (Chang \& Wang, 2011), consumers expect equal or higher levels of service quality, than customers in traditional 
brick-and-mortar store and as a result when online shoppers perceive high online service quality, they will exhibit high customer perceived value and become a satisfied customer. On the basis of the preceding, the following hypothesis is proposed:

$\mathrm{H}_{2}$. Online service quality will positively impact information value.

$\mathrm{H}_{3}$. Online trust will positively impact social value.

\section{The relationship between satisfaction and perceived value}

An important issue when studying consumer perceived value is to distinguish it from consumer satisfaction (Eggert and Ulaga 2002; Sweeney and Soutar, 2001). Sweeney and Soutar (2001) suggest that perceived value has been often defined at a broad level and sometimes confused with the consumer satisfaction concept (e.g., meeting consumers' needs). In fact, the concept of consumer value has a strong association with consumer satisfaction because both concepts describe evaluation and judgments of products and services in use situations (Spiteri and Dion, 2004). Woodruff and Gardial (1996:98) believe satisfaction and perceived value are dissimilar, with consumer perceived value being formulated at different stages of the purchase decision process, including the pre purchase stage. Sweeney and Soutar (2001) say that a perception of value can be created without the product or service being bought. In contrast, satisfaction has been claimed to be a post-consumption evaluation (Eggert and Ulaga 2002). According to Eggert and Ulaga, the assessment of consumer perceived value is directed toward former, present, and potential consumers, whereas satisfaction research is mainly geared toward the supplier's current consumer base.

However, the direct connection between consumer overall satisfaction and consumer perceived value remains controversial in the marketing literature. Researchers who suggest the consumer satisfaction $\rightarrow$ consumer perceived value direct relationship (e.g. Cronin et al, 2000) believe consumer perceived value is a higher ordered and more constant subjective judgment (reaction) than consumer satisfaction, hence consumer perceived value acts as outcome of the other post purchase evaluation constructs (consumer satisfaction). Researchers who suggest that consumer perceived value $\rightarrow$ consumer satisfaction is a causal relationship (e.g. Fornell et al, 1996) believe consumer perceived value works only as a predictor of consumer satisfaction reactions (judgments).

Cronin et al (2000) observe that consumers overall satisfaction, perceived quality and consumer perceived value are all measured in a global sense, and suggest that the perceived quality $\rightarrow$ satisfaction link can be expected to be very strong. They claim that because perceived quality is a driver of consumer overall satisfaction, it can be concluded that perceived quality leads to consumer satisfaction. In addition, a reverse connection between consumer satisfaction and consumer perceived value (that is, consumer perceived value $\rightarrow$ consumer satisfaction) is also feasible if the measurement of consumer satisfaction and consumer perceived value is carried out at the overall level (Cronin et al, 2000). Since both orders, consumer satisfaction $\rightarrow$ consumer perceived value and consumer perceived value $\rightarrow$ consumer satisfaction, appear to be logical; the relationship will be investigated in this study.

A review of the service marketing literature reveals perceived value as a contributing factor to 
consumer's satisfaction (Yang \& Peterson, 2004). In particular, customer satisfaction is viewed as a post consumption evaluation made by the consumer, regarding the bought product or service (Kim et al., 2012), and it is contended that value has a direct impact on how satisfied customers are with a vendor. Yang \& Peterson (2004) also found in their study that perceived value is an antecedent of customer satisfaction and they suggested that to enhance satisfaction, a service provider can spend its effort on improving the value perceived by customers.

The most important characteristic of the s-commerce is its facilitation of bi-directional communications between consumers and consumers, consumers and firms, and consumers and between consumers and third parties. Accordingly, consumers can be both information senders as well as receivers, accessing and participating in Internet communications through email and discussion lists, and chat rooms (Kim et al, 2004). Such Internet mechanisms allows consumers to share information about products, services, and firms with other consumers through online Social networks or so-called "virtual communities" Online consumer networks can be an information source in the purchase decision making of other consumers, (Evans and Wurster, 1999), as noted earlier.

Social networks allow consumers to share news, information, and experience in specific areas of interests (Cheung and lee, 2010), consumers can post a product review, and as well share the opinions, photos and videos with others by a user-friendly interface; and discussion groups can be formed for people with similar interest, and empower customers by providing them with the opportunity to spread a story of an unsatisfactory experience with greater reach than possible with direct word of mouth (Alshibly, 2014). Alshibly point out that the Internet also allows consumers to be more aware of corporate shortcomings, and to gain access to the legal system.

Therefore, information obtained from s-commerce is more meaningful than the information derived from other sources (e.g., search engine) ((Huang \& Benyoucef, 2013). From the view of the information perceived value, if consumers perceived the information provided by s-commerce website is useful, they will likely use the service and spend time using the s-commerce website. Hence, if the consumers perceived information value are high, they will be satisfied with s-commerce website.

Therefore, this study brings forth the following hypothesis:

$\mathrm{H}_{5}$ : An increase in information perceived value will lead to increase in customer satisfaction with an s-commerce website.

$\mathrm{H}_{6}$ : An increase in social perceived value will lead to increase in customer satisfaction with a s-commerce website.

According to the previous literature research, the following research model (Figure 1) was developed and applied as the theoretical framework for understanding the impact of online trust and online service quality on customer perceived value and the impact of information and social value on customers' satisfaction. 


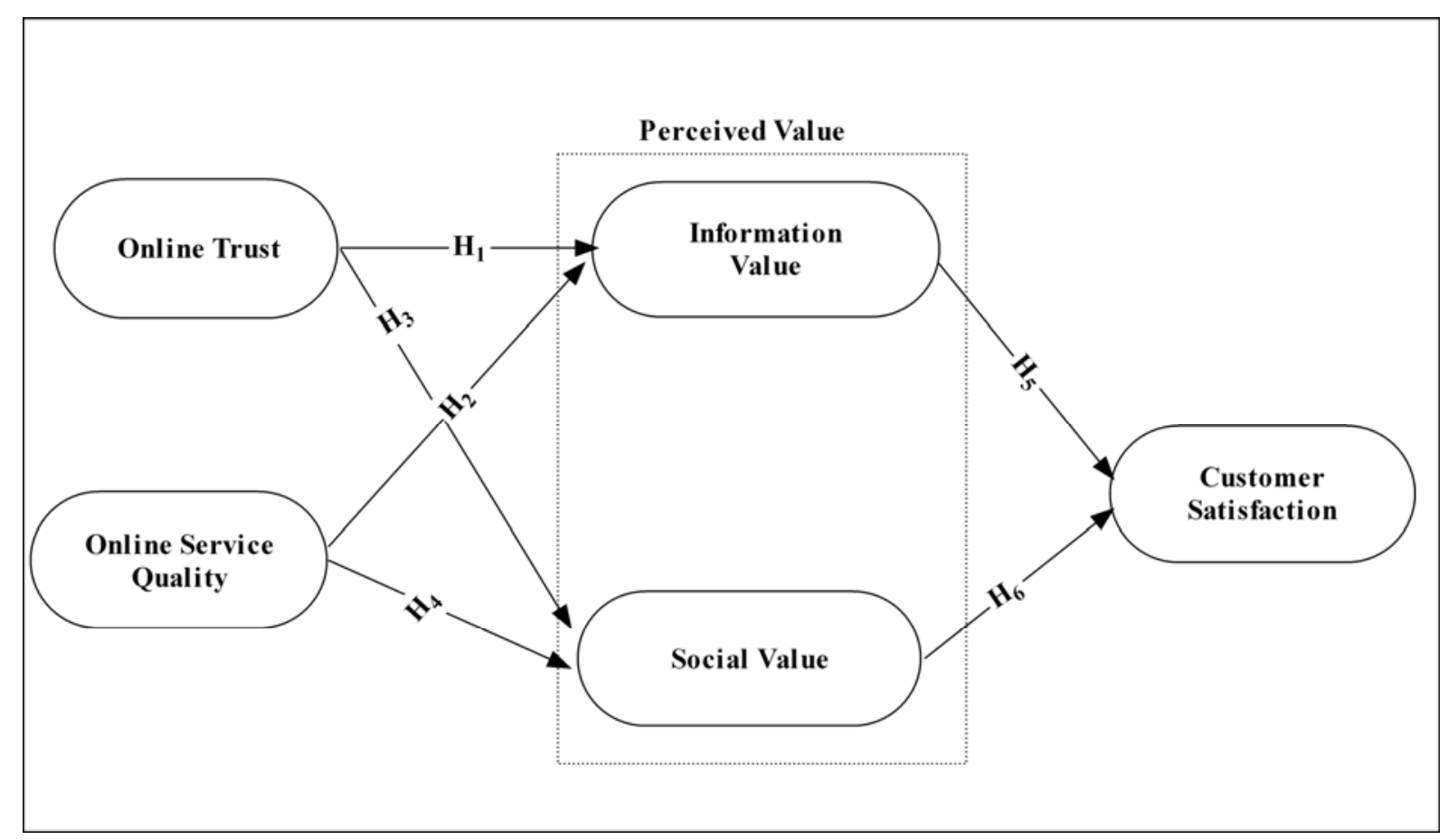

Figure 1. The research model

\section{Research methodology}

\section{Constructs Measurement and Questionnaire Design}

The items for each construct were adopted mainly from previous research but were modified to include s-commerce as the technology to be assessed. For example, Online trust is measured by using items adapted from (Kim and Park, 2013). Online Service quality is measured by four-item scales all adapted from (Yang et al., 2004). Information value and social value are measured by using items adapted from (Yang et al., 2004). Customer satisfaction used five-item scale measure all adapted from (Alshibly, 2014). All the measurement items were measured on a five-point Likert-type scales that was anchored by $1=$ strongly disagree to $5=$ strongly agree to express the degree of agreement. After the measurement variables were developed, the face validity of these variables was tested. Five management information systems scholar reviewed the measurement variables. In addition, ten management information systems graduate students reviewed the measurement variables and provided feedback on the length and clarity of each item. Based on the feedback the researchers received from the reviewers, any questions that caused confusion or where deemed potentially difficult to understand were dropped or replaced by new understandable items. Table 1 presents the research constructs and related survey items used for measurement of each of these constructs. 
Table 1. Measurement items for questionnaire

\begin{tabular}{|c|c|c|}
\hline Construct & Survey questions & Source \\
\hline $\begin{array}{l}\text { Online } \\
\text { Trust }\end{array}$ & $\begin{array}{l}\text { T1. This s-commerce firm gives the impression } \\
\text { that it keeps promises } \\
\text { T2. I believe This s-commerce firm has my best } \\
\text { interests in mind } \\
\text { T3. The community of s-commerce firm is trustworthy } \\
\text { T4. This s-commerce firm is trustworthy }\end{array}$ & $\begin{array}{l}\text { Kim and } \\
\text { Park,(2013) }\end{array}$ \\
\hline $\begin{array}{l}\text { Online } \\
\text { Service quality }\end{array}$ & $\begin{array}{l}\text { SQ1. This s-commerce firm performs the service correctly } \\
\text { the first time } \\
\text { SQ2. This s-commerce firm quickly resolves problems I } \\
\text { encounter } \\
\text { SQ3. This s-commerce firm provides services with the } \\
\text { features I want } \\
\text { SQ4. This s-commerce firm employees have the knowledge } \\
\text { to answer my } \\
\text { questions }\end{array}$ & $\begin{array}{l}\text { Yang et } \\
\text { al., } 2004\end{array}$ \\
\hline $\begin{array}{l}\text { Information } \\
\text { Value }\end{array}$ & $\begin{array}{l}\text { IV1. I can get information easily on this s-commerce firm } \\
\text { website. } \\
\text { IV2. Information obtained from this s-commerce firm } \\
\text { website is useful. } \\
\text { IV3. This s-commerce firm website makes acquiring } \\
\text { information easily. }\end{array}$ & 2013) \\
\hline Social & $\begin{array}{l}\text { SV1. I can contact with friends on this s-commerce firm } \\
\text { website. } \\
\text { SV2. I can share experiences with others on this s-commerce } \\
\text { firm website. } \\
\text { SV3. I can develop friendships with other users on this } \\
\text { s-commerce firm website. } \\
\text { SV4. I can extend personal relationship on this s-commerce } \\
\text { firm website. }\end{array}$ & Yen,(2013) \\
\hline $\begin{array}{l}\text { Customer } \\
\text { satisfaction }\end{array}$ & $\begin{array}{l}\text { S1. This s-commerce firm totally meets my expectations. } \\
\text { S2. Altogether, I'm satisfied with the goods and services of } \\
\text { This s-commerce firm } \\
\text { S3. I've made especially good experiences with this } \\
\text { s-commerce firm } \\
\text { S4. This s-commerce firm offers me exactly what I need. } \\
\text { S5. The overall feeling I used s-commerce puts me in a good } \\
\text { mood. }\end{array}$ & $\begin{array}{l}\text { Alshibly } \\
\text { (2014) }\end{array}$ \\
\hline
\end{tabular}




\section{Sampling and data collection}

Data for this research were collected using an electronic and paper questionnaire in April and May 2014. The questionnaire is sent to 400 Jordanian web users by email, including 149 answered our study, who joined various groups and community on social networks, especially on Facebook and who often visited e-shops from which they made purchases. These web users are keenly interested in web and virtual communities and have a culture in E-marketing that makes them a representative sample in the s-commerce. Participants were informed that the return of a completed survey would be taken as consent. However, as returned surveys would be anonymous, the information sheet advised that withdrawal of data after the return of the survey would not be possible.

149 valid questionnaires were returned from the subjects who had prior online purchase experience. The respondents were predominantly males $(64 \%)$ and females with a $(36 \%)$. The dominated age group is of between the age of 25-35 (36.5\%) followed by 35-45 (32\%) and 55\&older is the lowest (1\%). About (79\%) use home internet and (21\%) don't have .

\section{Data Analysis}

\section{Structural Equation Modelling Approach}

In order to statistically analyze the measurement and structural models, this study used Smart PLS software for partial least squares structural equation modelling (PLS-SEM) technique (Ringle et al., 2005). In PLS-SEM, the measurement model refers to the linkages between the latent variables and their manifest variables and the structural model captures the hypothesized causal relationships among the research constructs (Chin, 2010). PLS-SEM enables the simultaneous examination of both the path (structural) and factor (measurement) models in one model. In addition to that, PLS-SEM combines a factor analysis with near regressions, makes only minimal assumptions, with the goal of variance explanation (high Rsquare) (Hair et al., 2013). Furthermore, PLS-SEM supports both exploratory and confirmatory research, is robust to deviations for multivariate normal distributions, and is good for small sample size. Since the current study sample size is relatively small (149), PLS-SEM was found more appropriate and befitting the purpose of the current study.

The study applied PLS-SEM path modelling with a path-weighting scheme for the inside approximation (Chin, 2010). Then, we applied the non-parametric bootstrapping approximation (Hair et al., 2013) with 200 resampling to obtain the standard errors of the estimates.

\section{Measurement Model}

A measurement model of the conceptual model with five latent variables was estimated. All constructs were modelled using reflective indicators since the previous study have modelled them the same. First, Construct reliability was assessed using Composite Reliabilities (CR) values and Cronbach's Alpha (CA) values. As indicated in Table 2, the CR and the CA values are all above 0.7 recommended by Hair et al (2013). With values ranging from 0.84 to 0.89 
for CR and from 0.73 to 0.81 for all Cronbach's alphas, this study can conclude that the scales are reliable.

Table 2. Factor loadings, AVE, Composite Reliability and Internal Consistencies

\begin{tabular}{|c|c|c|c|c|c|c|}
\hline \multicolumn{2}{|l|}{$\begin{array}{l}\text { Research } \\
\text { Construct }\end{array}$} & $\begin{array}{l}\text { Indicator } \\
\text { Reliability }\end{array}$ & $\begin{array}{l}\text { Cronbach's } \\
\text { Alpha }\end{array}$ & $\begin{array}{l}\text { Composite } \\
\text { Reliability }\end{array}$ & AVE & $\begin{array}{l}\text { Factor } \\
\text { loadings }\end{array}$ \\
\hline \multirow{4}{*}{$\begin{array}{l}\text { Online } \\
\text { Trust }\end{array}$} & $\mathrm{T} 1$ & 0.66 & \multirow{4}{*}{0.78} & \multirow[t]{4}{*}{0.86} & \multirow[t]{4}{*}{0.61} & 0.81 \\
\hline & $\mathrm{T} 2$ & 0.71 & & & & 0.84 \\
\hline & T3 & 0.49 & & & & 0.70 \\
\hline & $\mathrm{T} 4$ & 0.57 & & & & 0.76 \\
\hline \multirow{4}{*}{$\begin{array}{l}\text { Online } \\
\text { Service quality }\end{array}$} & SQ1 & 0.49 & \multirow{4}{*}{0.79} & \multirow[t]{4}{*}{0.85} & \multirow[t]{4}{*}{0.60} & 0.70 \\
\hline & SQ2 & 0.49 & & & & 0.70 \\
\hline & SQ3 & 0.79 & & & & 0.89 \\
\hline & SQ4 & 0.84 & & & & 0.92 \\
\hline \multirow{3}{*}{$\begin{array}{l}\text { information } \\
\text { value }\end{array}$} & IV1 & 0.74 & \multirow{3}{*}{0.81} & \multirow[t]{3}{*}{0.89} & \multirow[t]{3}{*}{0.73} & 0.86 \\
\hline & IV2 & 0.77 & & & & 0.87 \\
\hline & IV3 & 0.68 & & & & 0.82 \\
\hline \multirow[t]{3}{*}{ Social value } & SV1 & 0.58 & \multirow{3}{*}{0.73} & \multirow{3}{*}{0.84} & \multirow[t]{3}{*}{0.64} & 0.76 \\
\hline & SV2 & 0.59 & & & & 0.77 \\
\hline & SV3 & 0.77 & & & & 0.88 \\
\hline \multirow{5}{*}{$\begin{array}{l}\text { Customer } \\
\text { satisfaction }\end{array}$} & S1 & 0.56 & \multirow{5}{*}{0.81} & \multirow{5}{*}{0.87} & \multirow[t]{5}{*}{0.55} & 0.75 \\
\hline & $\mathrm{S} 2$ & 0.43 & & & & 0.66 \\
\hline & S3 & 0.56 & & & & 0.75 \\
\hline & S4 & 0.64 & & & & 0.80 \\
\hline & S5 & 0.64 & & & & 0.80 \\
\hline
\end{tabular}

Next we proceeded to test the convergent validity, which is the degree to which multiple items measuring the same concept are in agreement. As suggested by Chin et al. (2010) we used the factor loadings and the average variance extracted (AVE) to assess convergent validity. The loadings for all items exceeded the recommended value of 0.5 (Hair et al., 2013). The average variance extracted, which reflects the overall amount of variance in the indicators accounted for by the latent construct, were in the range of 0.55 and 0.73 which exceeded the recommended value of 0.5 (Hair et al., 2013).

Then, we proceeded to test the discriminant validity. Discriminant validity is the extent to which the measures is not a reflection of some other variables and is indicated by the low correlations between the measure of interest and the measures of other constructs (Hair et al., 2013). 


\section{Mll Macrothink}

Discriminant validity can be examined by comparing the squared correlations between constructs and the average variance extracted for a construct (Fornell and Larcker, 1981).

As shown in Table 3, the squared correlations for each construct is less than the average variance extracted by the indicators measuring that construct indicating adequate discriminant validity. Finally, another approach to assessing discriminant validity involves examining the cross-loadings. Discriminant validity is established when an indicator's loading on a construct is higher than all of its cross loadings with other constructs.

Table 3. Inter-Construct Correlations and Shared Variance

\begin{tabular}{|l|l|l|l|l|l|}
\hline & $\begin{array}{l}\text { Online } \\
\text { trust } \\
\text { quality }\end{array}$ & $\begin{array}{l}\text { Online service } \\
\text { Information } \\
\text { value }\end{array}$ & $\begin{array}{l}\text { Social } \\
\text { value }\end{array}$ & $\begin{array}{l}\text { Customer } \\
\text { satisfactio } \\
\mathrm{n}\end{array}$ \\
\hline Online trust service & 0.60 & $\mathbf{0 . 7 7}$ & & & \\
\hline $\begin{array}{l}\text { Online } \\
\text { quality }\end{array}$ & 0.54 & 0.55 & $\mathbf{0 . 8 5}$ & & \\
\hline Information value & 0.55 & 0.60 & 0.54 & $\mathbf{0 . 8 0}$ & \\
\hline Social value & 0.65 & 0.62 & 0.67 & 0.67 & $\mathbf{0 . 7 4}$ \\
\hline $\begin{array}{l}\text { Customer } \\
\text { satisfaction }\end{array}$ & \begin{tabular}{l}
$|l|$ \\
\hline
\end{tabular} \\
Note: The bold elements on the diagonal represent the square roots of the average variance \\
extracted, and off-diagonal elements are the correlation estimates.
\end{tabular}

Table 4 shows that the study constructs indicator's loadings are higher than all of its cross loadings. Thus, discriminant validity has been established. In total, the measurement model demonstrated adequate convergent validity and discriminant validity. 


\section{Ml Macrothink}

Table 4. the loadings and cross loadings for the construct indicators

\begin{tabular}{|c|c|c|c|c|c|c|}
\hline & & Online Trust & $\begin{array}{l}\text { Online Service } \\
\text { Quality }\end{array}$ & $\begin{array}{l}\text { Information } \\
\text { Value }\end{array}$ & $\begin{array}{l}\text { Social } \\
\text { Value }\end{array}$ & $\begin{array}{l}\text { Customer } \\
\text { Satisfaction }\end{array}$ \\
\hline \multirow{4}{*}{$\begin{array}{l}\text { Online } \\
\text { Trust }\end{array}$} & $\mathrm{T} 1$ & 0.81 & 0.54 & 0.47 & 0.42 & 0.50 \\
\hline & $\mathrm{T} 2$ & 0.84 & 0.48 & 0.45 & 0.38 & 0.52 \\
\hline & T3 & 0.70 & 0.50 & 0.32 & 0.51 & 0.51 \\
\hline & $\mathrm{T} 4$ & 0.76 & 0.36 & 0.44 & 0.41 & 0.48 \\
\hline \multirow{4}{*}{$\begin{array}{l}\text { Online } \\
\text { Service } \\
\text { Quality }\end{array}$} & SQ1 & 0.50 & 0.70 & 0.35 & 0.30 & 0.43 \\
\hline & SQ2 & 0.05 & 0.55 & 0.25 & 0.13 & 0.19 \\
\hline & SQ3 & 0.51 & 0.89 & 0.49 & 0.58 & 0.53 \\
\hline & SQ4 & 0.62 & 0.92 & 0.53 & 0.64 & 0.64 \\
\hline \multirow{3}{*}{$\begin{array}{l}\text { Informati } \\
\text { on Value }\end{array}$} & IV1 & 0.46 & 0.51 & 0.86 & 0.42 & 0.59 \\
\hline & IV2 & 0.41 & 0.55 & 0.87 & 0.51 & 0.55 \\
\hline & IV3 & 0.51 & 0.34 & 0.82 & 0.46 & 0.56 \\
\hline \multirow{3}{*}{$\begin{array}{l}\text { Social } \\
\text { Value }\end{array}$} & SV1 & 0.39 & 0.43 & 0.36 & 0.76 & 0.47 \\
\hline & SV2 & 0.38 & 0.30 & 0.53 & 0.77 & 0.49 \\
\hline & SV3 & 0.53 & 0.66 & 0.44 & 0.88 & 0.64 \\
\hline \multirow{5}{*}{$\begin{array}{l}\text { Customer } \\
\text { Satisfacti } \\
\text { on }\end{array}$} & $\mathrm{S} 1$ & 0.46 & 0.41 & 0.57 & 0.53 & 0.75 \\
\hline & $\mathrm{S} 2$ & 0.50 & 0.45 & 0.46 & 0.53 & 0.66 \\
\hline & S3 & 0.52 & 0.54 & 0.41 & 0.59 & 0.75 \\
\hline & S4 & 0.47 & 0.48 & 0.53 & 0.46 & 0.80 \\
\hline & S5 & 0.47 & 0.44 & 0.53 & 0.40 & 0.80 \\
\hline
\end{tabular}

\section{Structural Modeling Results}

The structural model was tested using the loadings and significance of the path coefficients, indicate the strengths of relationships between dependent and independent variables, and the $\mathrm{R}^{2}$ value which represents the amount of variance explained by independent variables. Values of approximately 0.35 are considered substantial, values around 0.333 moderate, and values of approximately 0.190 weak (Martinez-Ruiz and Aluja- Banet, 2009). To test the significance of the hypotheses, the rule proposed by Martinez-Ruiz and Aluja- Banet (2009) was followed. The $t$-value $>1.65$ is significant at the 0.05 level, and the $t$-value $>2$ is significant at the 0.01 level. The statistical significance of each path was estimated using a Smart PLS bootstrapping method utilizing 500 resamples to obtain t-values (Chin, 1998). Figure 2 and Table 5 presents the results of the PLS analysis on the structural model along with the path estimates and t-values. Support for the study hypotheses, which are labelled on their corresponding paths in Figure 2, could be ascertained by examining the directionality (positive or negative) of the path 


\section{Macrothink}

coefficients and the significance of the t-values. The standardized path coefficients are expected to be at least 0.2 and preferably greater than 0.3 (Chin, 2010).

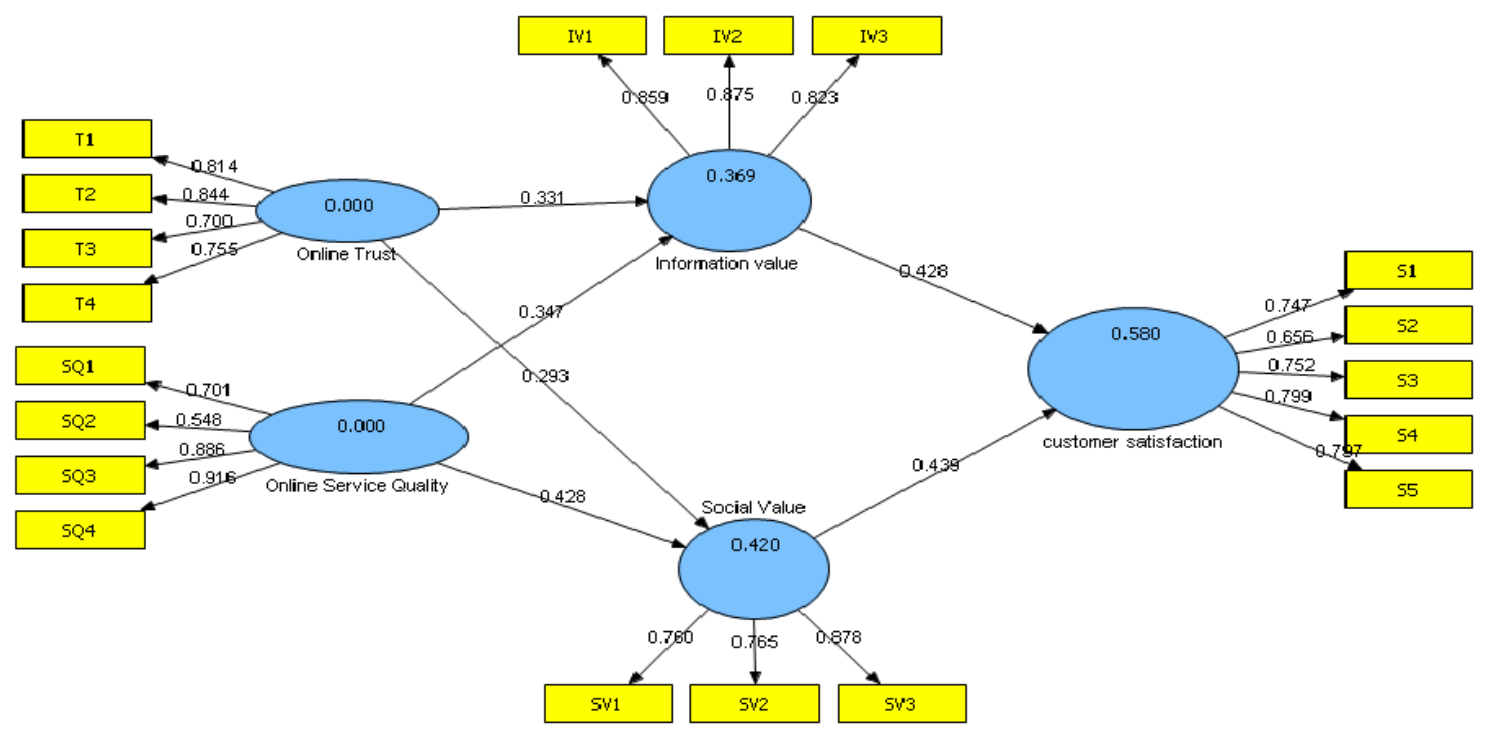

Figure 2. Measurement and Structural Model Results

The results in Table 5 and Figure 2 provide support for the six hypotheses $\left(\mathrm{H}_{1}, \mathrm{H}_{2}, \mathrm{H}_{3}, \mathrm{H}_{4}, \mathrm{H}_{5}\right.$ and $\left.\mathrm{H}_{6}\right)$. Online trust $(\beta=0.33, \mathrm{p}<0.001)$ and online service quality $(\beta=0.35, \mathrm{p}<0.001)$ had a significant impact on information value. Thus $\mathrm{H}_{1}$ and $\mathrm{H}_{2}$ were supported. The standardized $\operatorname{Beta}(\beta)$ value for Online Trust $=0.33$ and for online service quality $\beta=0.35$ shows that Online Service Quality has more impact than Online Trust on Information value. In addition, Online Trust $(\beta=0.29, \mathrm{P}<0.001)$ and Online Service Quality $(\beta=0.43, \mathrm{P}<0.001)$ had a significant impact on Social Value. This is consistent with the prediction of $\mathrm{H}_{3}$ and $\mathrm{H}_{4}$ and is supported.

Finally, the results provide support for $\mathrm{H}_{5}$ and $\mathrm{H}_{6}$, which predicted positive relationships between Information value $(\beta=0.43, \mathrm{P}<0.001)$ and satisfaction, and between social value ( $\beta$ $=0.44, \mathrm{P}<0.001)$ and customer satisfaction. The standardized Beta $(\beta)$ value for social value $=$ 0.44 and for Information value $\beta=0.43$ shows that Social Value has more impact than Information value on satisfaction. In terms of the $\mathrm{R}^{2}$ value for each endogenous variable, the two variables explained $58 \%$ of the variance in satisfaction. 
Table 5. Results of Structural Equation Model Analysis

\begin{tabular}{|c|c|c|c|c|c|}
\hline Hypotheses & Path & $\beta$ & $\mathrm{R}^{2}$ & T Statistics & Decision \\
\hline $\mathrm{H}_{1}$ & Online Trust $->$ Information value & 0.33 & \multirow[t]{2}{*}{0.37} & 4.89 & Supported \\
\hline $\mathrm{H}_{2}$ & Online Service Quality -> Information value & 0.35 & & 5.76 & Supported \\
\hline $\mathrm{H}_{3}$ & Online Trust -> Social Value & 0.29 & \multirow[t]{2}{*}{0.42} & 4.77 & Supported \\
\hline $\mathrm{H}_{4}$ & Online Service Quality -> Social Value & 0.43 & & 6.32 & Supported \\
\hline $\mathrm{H}_{5}$ & Information value -> customer satisfaction & 0.43 & \multirow[t]{2}{*}{0.58} & 8.11 & Supported \\
\hline $\mathrm{H}_{6}$ & Social Value -> customer satisfaction & 0.44 & & 9.52 & Supported \\
\hline
\end{tabular}

\section{Discussion and implications, limitations, and future research}

The objective of this study was to increase the understanding of the relationship between, online service quality, online trust and customer perceived value within the s-commerce environment and their influence on customer satisfaction. The results provided support for the theoretical model of this study. In particular, the study identified that all dimensions of perceived value were found to have a significant effect on customer satisfaction. Specifically, the study found that both social value and information value to have a significant effect on customer satisfaction. Therefore, an increasing in customer perceived value is an important marketing tool to maintain customer satisfaction in s-commerce websites. One of the challenging tasks that online seller face is how to enhance customer satisfaction. As suggested by our model, customer satisfaction will develop if the dimensions of customer perceived value is well managed. Therefore, online service marketing strategies may be more fruitful through focusing on these psychological processes.

For researchers, the present findings are a first step towards an in-depth understanding of the operationalization and key dimensions of perceived value and their differentiated effects on customer satisfaction. It is true that superior perceived value is very important for the successful competition of firms in customer-centred era, which has been explored and examined conceptually and empirically by many studies. However, which dimensions or elements of perceived value most focus are unsolved questions that are in urgent need to be explored. Therefore, on the basis of the present findings, researchers will be able to explore other dimensions of perceived value and other factors that influence customer satisfaction.

Past studies often used different dimensions to measure customer perceived value, but this study verifies two constructs social value and information value into customer perceived value in s-commerce context. Both social value and information value are major attractors of s-commerce in general portraying the ease of getting the information compared to other alternatives and support for the importance of social aspects in customer satisfaction enhancement. Hence, social value may be of more significant importance in online that emphasize social interaction within a group, especially in s-commerce context. Therefore, 
marketing activities in s-commerce should focus on facilitating efficient social experiences. For example, some s-commerce websites currently provides an in-browser instant messenger client allowing users to chat instantly with any friends online.

Furthermore, the study identified that online trust and online service quality are factors having direct influence on customer information and social value. It was found, however, that online service quality is the strongest predictor of customer perceived value.

Based on the finding of this study online service quality influences customer perceived value in s-commerce, That is, an increase in the quality of the s-commerce website service improve the customers perceived value of the service. Therefore, the current study investigate this contentious issues in an often most neglected research context and the findings of this empirical study are expected to provide fruitful new insights and implications to both academicians and practitioners across the globe.

Overall, the positive relationship between online service quality and customers perceived value should further motivate managers to consider adding additional service quality features to their sites. Therefore, this research made contributions to the current knowledge, providing empirical evidences that customers' perceived value on the s-commerce is positively associated with online service quality.

As the result indicates online trust appears to be important for improving the customers perceived value, which implies that, in order to attract more current customers to repurchase online, the service providers must try to establish an impression that they are honest to their customers and care about customers' needs, which can then enhance the degree of customers' perceptions of trust.

These results need to be interpreted within the limitations of the study since it is only recently that the understanding of the operationalization and key dimensions of perceived value and their impacts on customer satisfaction became the priority of both managers and researchers. A potential limitation of this study was limitations arising from the sample used in this study. The participants were not taken from a probability sample. Although there was no evidence of sample biases compared to the population from which the sample was drawn, this possibility cannot be ruled out. The acknowledged limitations of this study have led to suggestions for further research.

While the findings reported in this study go some way to resolving the research problem outlined, much remains unresolved. Accordingly, three broad areas are suggested for future research direction. These research directions are (1) expansion of the study model, including new antecedents or dimensions of customers perceived value; (2) further exploration of hypothesized relationships, including new methods of investigation; (3) exploration of the relationship between the study variables.

\section{References}

Aladwani, A. M., \& Palvia, P. C. (2002). Developing and validating an instrument for measuring user-perceived web quality. Information \& management, 39(6), 467-476. 
Alshibly, H. H. (2014). A free simulation experiment to examine the effects of social commerce website quality and customer psychological empowerment on customers' satisfaction. Journal of Business Studies Quarterly, 5(4), 21-40.

Bakos, J. Y. (1991). A strategic analysis of electronic marketplaces. MIS quarterly, 295-310.

Bolton, R. N., \& Drew, J. H. (1991). A multistage model of customers' assessments of service quality and value. Journal of consumer research, 17(4), 375-384. http://dx.doi.org/10.1086/208564

Brynjolfsson, E., \& Smith, M. D. (2000). Frictionless commerce? A comparison of Internet and conventional retailers. Management Science, 46(4), 563-585. http://dx.doi.org/10.1287/mnsc.46.4.563.12061

Carlson, J., \& O'Cass, A. (2010). Exploring the relationships between e-service quality, satisfaction, attitudes and behaviours in content-driven e-service web sites. Journal of Services Marketing, 24(2), 112-127. http://dx.doi.org/10.1108/08876041011031091

Celuch, K., Goodwin, S., \& Taylor, S. A. (2007). Understanding small scale industrial user internet purchase and information management intentions: a test of two attitude models. Industrial Marketing Management, $\quad 36(1), \quad$ 109-120. http://dx.doi.org/10.1016/j.indmarman.2005.08.004

Chang, H. H., \& Wang, H. W. (2011). The moderating effect of customer perceived value on online shopping behaviour. Online Information Review, 35(3), 333-359.

Chen, Z., \& Dubinsky, A. J. (2003). A conceptual model of perceived customer value in e-commerce: A preliminary investigation. Psychology \& Marketing, 20(4), 323-347.

Cheung, C. M., \& Lee, M. K. (2010). A theoretical model of intentional social action in online social networks. Decision support systems, $\quad 49(1), \quad$ 24-30. http://dx.doi.org/10.1016/j.dss.2009.12.006

Chin WW. How to write up and report PLS analyses. In: Handbook of Partial Least Squares: Concepts, Methods and Application. Esposito Vinzi, V.; Chin, W.W.; Henseler, J.; Wang, H. (Eds.).Springer. Germany. 2010. 645-689.

Collier, J. E., \& Bienstock, C. C. (2006). Measuring service quality in e-retailing. Journal of service research, 8(3), 260-275. http://dx.doi.org/10.1177/1094670505278867

Cronin Jr, J. J., Brady, M. K., \& Hult, G. T. M. (2000). Assessing the effects of quality, value, and customer satisfaction on consumer behavioral intentions in service environments. Journal of retailing, 76(2), 193-218. http://dx.doi.org/10.1016/S0022-4359(00)00028-2

Delone, W. H., \& Mclean, E. R. (2003). The DeLone and McLean Model of Information Systems Success: A Ten-Year Update. Journal of Management Information Systems, 19(4), 9-30. 
Delone, W. H., \& Mclean, E. R. (2004). Measuring e-commerce success: Applying the DeLone \& McLean information systems success model. International Journal of Electronic Commerce, 9(1), 31-47.

Feeny, D. (2001). Making Business Sense of the E-Opportunity. MIT Sloan Management Review, 42(2), 41-51.

Fornell, C., \& Larcker, D. F. (1981). Evaluating structural equation models with unobservable variables and measurement error. Journal of marketing research, 18(1), 39-50. http://dx.doi.org/10.2307/3151312

Fornell, C., Johnson, M. D., Anderson, E. W., Cha, J., \& Bryant, B. E. (1996). The American customer satisfaction index: nature, purpose, and findings. The Journal of Marketing, 60(4), 7-18. http://dx.doi.org/10.2307/1251898

Gefen, D. (2000). E-commerce: the role of familiarity and trust. Omega, 28(6), 725-737. http://dx.doi.org/10.1016/S0305-0483(00)00021-9

Gefen, D., \& Straub, D. W. (2004). Consumer trust in B2C e-commerce and the importance of social presence: experiments in e-products and e-services. Omega, 32(6), 407-424. http://dx.doi.org/10.1016/j.omega.2004.01.006

Gefen, D., Karahanna, E., \& Straub, D. W. (2003). Trust and TAM in online shopping: an integrated model. MIS quarterly, 27(1), 51-90.

Grewal, D., Iyer, G. R., Krishnan, R., \& Sharma, A. (2003). The Internet and the price-value-loyalty chain. Journal of Business Research,56(5), 391-398. http://dx.doi.org/10.1016/S0148-2963(01)00227-2

Grewal, D., Monroe, K. B., \& Krishnan, R. (1998). The effects of price-comparison advertising on buyers' perceptions of acquisition value, transaction value, and behavioral intentions. The Journal of Marketing, 62(2), 46-59. http://dx.doi.org/10.2307/1252160

Hair J.F., Hult G.T., Ringle C.M., \& Sarstedt M. (2013). A Primer on Partial Least Squares Structural Equation Modelling (PLS-SEM). 1 ed. Thousand Oaks: Sage; 2013.

Hsiao, K. L., Lin, J. C. C., Wang, X. Y., Lu, H. P., \& Yu, H. (2010). Antecedents and consequences of trust in online product recommendations: an empirical study in social shopping. Online Information Review, 34(6), 935-953. http://dx.doi.org/10.1108/14684521011099414

Huang, Z., \& Benyoucef, M. (2013). From e-commerce to social commerce: a close look at design features. Electronic Commerce Research and Applications, 12(2), 246-259. http://dx.doi.org/10.1016/j.elerap.2012.12.003

Kim, C., Galliers, R. D., Shin, N., Ryoo, J. H., \& Kim, J. (2012). Factors influencing Internet shopping value and customer repurchase intention.Electronic Commerce Research and Applications, 11(4), 374-387. http://dx.doi.org/10.1016/j.elerap.2012.04.002 
Kim, K. K. (1989). User Satisfaction: A Synthesis of Three Different Perspectives. Journal of Information Systems, 12, 1-12

Kim, S., \& Park, H. (2013). Effects of various characteristics of social commerce (s-commerce) on consumers' trust and trust performance. International Journal of Information Management, 33(2), 318-332.

Ladhari, R. (2009). A review of twenty years of SERVQUAL research. International Journal of Quality and Service $\quad$ Sciences, 1(2), 172-198. http://dx.doi.org/10.1108/17566690910971445

Martinez-Ruiz, A., \& Aluja-Banet, T. (2009). Toward the definition of a structural equation model of patent value: PLS path modelling with formative constructs. REVSTAT-Statistical Journal, 7(3), 265-290.

McKnight, D. H., Choudhury, V., \& Kacmar, C. (2002). Developing and validating trust measures for e-commerce: an integrative typology. Information systems research, 13(3), 334-359. http://dx.doi.org/10.1287/isre.13.3.334.81

Morgan, R. M., \& Hunt, S. D. (1994). The Commitment-Trust Theory of Relationship Marketing. Journal of Marketing, 58(3), 20-38. http://dx.doi.org/10.2307/1252308

Parasuraman, A., \& Grewal, D. (2000). The impact of technology on the quality-value-loyalty chain: a research agenda. Journal of the academy of marketing science, 28(1), 168-174. http://dx.doi.org/10.1177/0092070300281015

Parasuraman, A., Zeithaml, V. A., \& Malhotra, A. (2005). ES-QUAL a multiple-item scale for assessing electronic service quality. Journal of service research, 7(3), 213-233.

Pennington, R., Wilcox, H. D., \& Grover, V. (2003). The role of system trust in business-to-consumer transactions. Journal of Management Information Systems, 20(3), 197-226.

Piccoli, G., Brohman, M. K., Watson, R. T., \& Parasuraman, A. (2004). Net-Based Customer Service Systems: Evolution and Revolution in Web Site Functionalities. Decision Sciences, 35(3), 423-455.

Ringle CM, Wende S. and Will A. (2005), "SmartPLS 2.0 M3 (beta). Hamburg. Retrieved from http://www.smartpls.de

Spiteri, J. M., \& Dion, P. A. (2004). Customer value, overall satisfaction, end-user loyalty, and market performance in detail intensive industries. Industrial Marketing Management, 33(8), 675-687. http://dx.doi.org/10.1016/j.indmarman.2004.03.005

Sweeney, J. C., \& Soutar, G. N. (2001). Consumer perceived value: the development of a multiple item scale. Journal of retailing, 77(2), 203-220. http://dx.doi.org/10.1016/S0022-4359(01)00041-0

Teo, T. S. (2001). Demographic and motivation variables associated with Internet usage activities. Internet Research, 11(2), 125-137. http://dx.doi.org/10.1108/10662240110695089 
Torkzadeh, G., \& Dhillon, G. (2002). Measuring factors that influence the success of Internet commerce. Information Systems Research, 13(2), 187-204. http://dx.doi.org/10.1287/isre.13.2.187.87

Urban, G. L., Sultan, F., \& Qualls, W. J. (2000). Placing trust at the center of your internet strategy. Sloan Management Review, 42(1), 319-33.

Venkatesh, V., Morris, M. G., Davis, G. B., \& Davis, F. D. (2003). User acceptance of information technology: Toward a unified view. MIS quarterly, 27(3), 425-478.

Woodall, T. (2003). Conceptualising 'value for the customer': an attributional, structural and dispositional analysis. Academy of Marketing Science Review, 12(1), 1-42..

Woodruff, R. B., \& Gardial, S. F. (1996), Know Your Customer: New Approaches To Understanding Customer Value And Satisfaction. Cambridge, MA: Blackwell

Woodruff, R. B. (1997). Customer Value: The Next Source for Competitive Advantage. Journal of the Academy of Marketing Science, 25(2), 139-53. http://dx.doi.org/10.1007/BF02894350

Yang, Z., \& Peterson, R. T. (2004). Customer perceived value, satisfaction, and loyalty: the role of switching costs. Psychology \& Marketing, 21(10), 799-822. http://dx.doi.org/10.1002/mar.20030

Yang, Z., Jun, M., \& Peterson, R. T. (2004). Measuring customer perceived online service quality: scale development and managerial implications. International Journal of Operations \& Production Management, $\quad 24(11), \quad 1149-1174$. http://dx.doi.org/10.1108/01443570410563278

Yen, Yung-Shen. (2013). Exploring Perceived Value in Social Networking Sites: The Mediation of Customer Satisfaction. International Journal of Computer and Information Technology, 3(2), 386-393.

Zeithaml, V. A. (1988). Consumer perceptions of price, quality, and value: a means-end model and synthesis of evidence. The Journal of Marketing, 2-22. http://dx.doi.org/10.2307/1251446

Zeithaml, V. A., Parasuraman, A., \& Malhotra, A. (2002). Service quality delivery through web sites: a critical review of extant knowledge. Journal of the academy of marketing science, 30(4), 362-375. http://dx.doi.org/10.1177/009207002236911 